Article

\title{
Guidelines for Tourism Sustainability in Ultra-Peripheral Territories: A Research Based on the Azores Region's Touristic Companies' Analysis
}

\author{
Gualter Couto ${ }^{1}\left(\mathbb{D}\right.$, Rui Alexandre Castanho ${ }^{1,2,3,4,5, * \mathbb{C}}$, Carlos Santos ${ }^{1}$, Pedro Pimentel ${ }^{1}\left(\mathbb{D}\right.$, Áurea Sousa ${ }^{6}(\mathbb{D}$, \\ Sandra Faria ${ }^{1,7}$ and Maria da Graça Batista ${ }^{1}$
}

check for

updates

Citation: Couto, G.; Castanho, R.A.; Santos, C.; Pimentel, P.; Sousa, Á.;

Faria, S.; Batista, M.d.G. Guidelines for Tourism Sustainability in

Ultra-Peripheral Territories: A

Research Based on the Azores Region's Touristic Companies' Analysis. Sustainability 2021, 13, 3895. https://doi.org/10.3390/su13073895

Academic Editor:

Elżbieta Grzelak-Kostulska

Received: 25 February 2021

Accepted: 28 March 2021

Published: 1 April 2021

Publisher's Note: MDPI stays neutra with regard to jurisdictional claims in published maps and institutional affiliations.

Copyright: (c) 2021 by the authors. Licensee MDPI, Basel, Switzerland. This article is an open access article distributed under the terms and conditions of the Creative Commons Attribution (CC BY) license (https:// creativecommons.org/licenses/by/ $4.0 /)$.
1 School of Business and Economics and CEEAplA, University of Azores, 9500-321 Ponta Delgada, Portugal; gualter.mm.couto@uac.pt (G.C.); carlos.as.santos@uac.pt (C.S.); pedro.ms.pimentel@uac.pt (P.P.); sandra.mc.faria@uac.pt (S.F.); maria.gc.batista@uac.pt (M.d.G.B.)

2 Faculty of Applied Sciences, WSB University, 41-300 Dąbrowa Górnicza, Poland

3 CITUR-Madeira-Centre for Tourism Research, Development and Innovation, 9000-082 Funchal-Madeira, Portugal

4 VALORIZA-Research Centre for Endogenous Resource Valorization, Polytechnic Institute of Portalegre (IPP), 7300-110 Portalegre, Portugal

5 Aquageo Ambiente Legal, University of Campinas, Brazil (UNICAMP), Campinas 13083-970, Brazil

6 Faculty of Sciences and Technologies and CEEAplA, University of Azores, 9500-321 Ponta Delgada, Portugal; aurea.st.sousa@uac.pt

7 Advance/CSG, ISEG, University of Lisbon, 1200-781 Lisbon, Portugal

* Correspondence: acastanho@wsb.edu.pl; Tel.: +351-912494673

Abstract: Tourism is an important activity to achieve territorial sustainability. In fact, a properly planned long-term tourism activity is critical for the regional planning to reach the desired living conditions capable of attracting new residents in the future. Thereby, the present research aims to assess the perceptions of the managers of tourist companies in the Azores on sustainability actors about the sustainability of tourism activity in the archipelago. Contextually, throughout an exploratory methodology, it was possible to assess the Azores Touristic Companies managers' perceptions. Hence, this paper shows that the sustainable practices most frequently adopted by the surveyed companies are the following: prioritize the purchase of regional goods and services $(94.7 \%)$; selective waste separation (94.5\%); minimize the use of hazardous substances or replace them with less hazardous products (92.3\%); ensure the proper final destination of wastewater (public sanitation, septic tank) (88.8\%); and adopt purchasing criteria that take into account environmentally friendly products or services $(88.6 \%)$. This research also recognizes that $67 \%$ of the respondents consider that the respective participating companies have their goals aligned with environmental conservation principles, $66.7 \%$ aligned with environmental conservation principles, $36.9 \%$ aligned with social conservation principles and $26.4 \%$ aligned with cultural conservation principle.

Keywords: Azores region; regional planning; tourism companies; sustainable tourism

\section{Introduction}

Tourism is a multidisciplinary activity [1-3]. In fact, tourism is an activity interlinked with businesses that collaborate to ensure the attraction of tourists [4].

Tourism development improves tourism facilities and activities to attract visitors, including the sustainability of these activities to serve tourists, community members, and the tourism destination $[4,5]$.

Contextually, we should consider rural tourism's fundamental role to be achieving the so-desired territorial sustainability [6-10].

In this regard, authors as Labrianidis et al. [11] defend that entrepreneurship associated with small and medium-sized businesses, is one way to achieve sustainable development 
in peripheral regions as it increases employment and income. The experimental results of research that discussed the variation of entrepreneurship among areas of different sizes showed a significant impact on the entry and exit of new companies [12]. This impact is harmful to the primary and secondary sectors, while this impact is positive for the services sector [12].

In addition, employment in tourism makes a significant contribution to the development of national and regional economies [1,13]. Practical evidence shows that tourist spending generates more jobs and income than any other sector of the economy and creates and maintains jobs in other sectors of the economy that sell to visitors and tourist companies. This is confirmed by many studies (see: [14-18]).

Based on the above-mentioned, the following research questions were raised:

(i) What is perception of the Azorean tourism companies on the sustainability of tourism in this Ultra-Peripheral territory?

(ii) Which should be the tourism model followed by the Azores to promote rural tourism and regional sustainable development?

Thereby, to answer the above research questions, we used carried out a brief literature review based on the topics of sustainable tourism, rural tourism, and regional development in order not only to possible identify some gaps in the literature but also to use this knowledge as a contribution for this study discussions and consequently guidelines for the development of sustainable tourism in this ultra-peripheral region. In this regard, we have also used a testing methodology to assess Azorean tourist companies' perceptions about the sustainability of tourism in the region.

Finally, this article aims at contributing to the theme of perceived sustainability measures taken by tourist companies and the provision of accessible and inclusive tourism services in the Azores.

\section{The Sustainable Tourism: Rural Tourism and Regional Development}

The United Nations World Tourism Organisation (UNWTO) [19] defined tourism as " (... ) the activities of persons traveling and staying in places outside their usual environment for not more than one consecutive year for leisure, business, and other purposes." Based on this description, three components should be introduced: (a) transportation outside; (b) reason for traveling; and (c) the maximum number of days stayed [20].

Contextually, tourism improvement improves tourism facilities or activities to attract visitors, including the sustainability of these activities to serve tourists, community members, and the tourism destination. The resilience of a tourism destination should be advanced [21].

Within the several tourism typologies, there are some more connected with rural tourism activity. Therefore, considering this research's scope, agritourism, ecotourism, nature-based tourism, or wine tourism deserve a closer look.

Therefore, agritourism can be defined as an activity that inspires travelers to visit farms [22]. Different forms of agritourism exist, specifically farm, farm-based and rural tourism [23]. Sonnino [24] defines an agricultural producer's and their family's hospitality actions that link to any form of farming. Barbieri and Mshenga [25] identified agritourism as the operation developed to draw visitors to an operative farm. In some cases, these visitors are from urban areas rather than rural areas in which the farm is located [26]. Most of these individuals engage in substance farming. Here we exclude commercial farming, which is on a wider scale. Agritourism includes wine tourism, farmers' markets, or fruit picking, are just some examples.

Ecotourism intends to produce knowledge, generate capital for conservation, improve awareness of cultures, and, lastly, better regional communities, economic inclusion, and political power [27-29]. This kind of tourism brings tourists to a region that encompasses the fauna, flora, and culture. In this regard, we also have geotourism, a tourism type that recognizes the physical environment that cultivates conservation through education and 
other procedures [30]. As examples of geotourism activities, we have geo-trails, protected area visits, or guided tours [27-29].

Wine tourism includes more than just the consumption of wine [27]. In fact, authors as Mitchell and $\mathrm{Li}$ [31] differentiated among primary wine tourism: wine tasting and procurement, and secondary or 'peripheral' wine tourism motivations-i.e., festivals and gastronomy. Moreover, wine consumption close to the area where the wine was made is identified as wine tourism or enotourism $[27,28]$.

\section{Rural Tourism and Regional Development}

Besides all the previously knew benefits of developing tourism in a region as economic profit, the growth of a tourism destination could bring a sense of pride for local communities-i.e., cherishing culture and history [26].

Besides, event tourism raises the attention and encourages local relationships; moreover, well-organized events could create a positive image of a tourism destination [28].

According to scholars as Smith [29], government authorities on a national, regional, and local level significantly impact tourism development through their policy implementation. Moreover, though the relationship between the development of the tourism industry and socio-economic progress has been investigated and accepted as an existing association, this relationship's impact has not been studied to the degree that it is meaningful [30]. Preservation of the environment could likewise be made feasible by tourism activities creating an income [27]. According to Rizzi and Graziano [31], the tourism industry popularizes resources and creates new destination images in regional and local economic development.

In this regard, there are specific events and festivals-i.e., food festivals, wine festivals, music festivals, among many others; that could foster the development of sustainable destinations [32]. Thus, it is possible to highlight the following events: Cheese Fair in Trujillo (Spain); Opera Festival in Sigulda (Latvia); Equestria Festival (France); or the Festival of Wine in Borba (Portugal), are just a few examples.

\section{The Ultra-Peripheral Region of Azores and Its Sustainable Development and Rural Tourism}

The Azores has several high-quality tourism resources, especially natural resources. Cultural resources also have significant potential, in addition to the quality of the resources created. The region has developed sustainable competitive advantages based on these resources and consolidated a powerful position in the nature tourism market.

The new air transport business model that entered into force in the Azores in March 2015 proved that small changes could make a big difference in international tourist flows and maximize the use of the region's potential. There is, therefore, a need to continuously create new strategies to capitalize on the potential of local tourism resources, which often means that new and more complex products, services, and experiences need to be designed.

The process of drafting the Strategic and Marketing Plan for Tourism in the Azores (PEMTA) was based on a participatory approach that involved several local stakeholders, including tourism agents, tour operators, and residents that objectively identified the major benefits the Region offers as a tourist destination. The main conclusions drawn from the process highlight natural resources as those that make the most significant contribution to tourism development in the Azores.

Security was also identified as a characteristic feature of the Azores, particularly relevant in the current geopolitical climate. Furthermore, residents acknowledge that tourism is a crucial driver of economic development, making it relatively easy to engage them in the sector's strategy and in the continuous creation of a safe society that respects visitors.

As a result, the PEMTA highlights the climate, biodiversity, quality of the landscape, geodiversity, culture, traditions, and built heritage as some of the Azores' most appealing and competitive features. Hence, nature tourism is a justified choice as a priority product for the international positioning of the Region.

Some authentic attributes of the local population were also indicated as having the potential to differentiate and diversify experiences on the nine islands. Proximity, unique- 
ness, and authenticity, among others, each island has many characteristics, in addition to the already mentioned security. These features make for an extraordinary backdrop for tourism development in general but are also great opportunities for high-value-added, exclusive, and highly sustainable products.

In the Azores Autonomous Region, tourism management models and those for regional socio-economic development include the basic principles of sustainability, centering on preserving and conserving the islands' endogenous resources. Technical documents as the Regional Sustainable Development Plan for the Autonomous Region of the Azores (PREDSA), the Tourism Spatial Development Plan for the Autonomous Region of the Azores (POTRAA), the Research and Innovation Strategies for Smart Specialization in the Azores (RIS3 Azores), or the Strategic and Marketing Plan for Tourism in the Azores (PEMTA) completely stress these problems, addressing them proper benchmarks of regional development [33].

Scholars as Couto et al. [34] state that "the Azores have received several international awards and distinctions in recognition of the islands' sustainable development and sustainable tourism." Unique classifications and labels-i.e., Biosphere Reserve, OSPAR Convention, RAMSAR Convention, Natura 2000 Network, and World Heritage-have also been assigned to some natural areas and heritage sites. Lately, the Azores was designated the "Best Sustainable Destination in the Atlantic," a significant achievement for the Region's tourism and an acknowledgment of the quality of tourism on the islands, since the Azores' governing bodies continue to strengthen the destination's position regarding sustainability issues. Contextually, the process to approve the Region as a "Sustainable Destination" according to the Global Sustainable Tourism Council (GSTC) criteria is currently underway. Should it be granted, it will be an unprecedented certification of destinations in the archipelago, strengthening the Region as a benchmark destination and bringing with it new competitive advantages [35]. The Azores' main features and resources are extensively identified, characterized, documented, and disseminated. They must be used by adequately structuring products and services for such a purpose. Some products may be designed for a niche, while others may encompass more significant segments. However, the potential to generate wealth will be far more related to creating added value than to the volume of demand. In addition to nature tourism, these high potential products are nautical tourism, cultural tourism, gastronomy tourism, religious tourism, adventure tourism, ecotourism, sports tourism, and wellness tourism, in particular thermalism.

Nature-based tourism strengthens the Azores as a tourism destination, not only regarding the contemplative aspects and ecotourism but also through action and engaging activities. A tourist can quietly contemplate the islands' landscape, be very active, experience unforgettable emotions, and enjoy memorable experiences [36]. Thus, nature-based tourism, particularly the active segment, was selected as the Azores' tourism development priority product. As the core product in the region's strategy guides the destination's positioning and its promotional actions. In order to diversify the offering, nautical tourism, cultural and landscape touring, and health and wellness tourism were selected as complementary sectors [36].

In this regard, the Azores' tourism strategy includes the valuation of the authenticity of and differences between the archipelago's nine islands, which is inherent to the concept of sustainability. Each island's positioning must consider its specific characteristics, local offering, and what drives each market segment. Indeed, each island has a set of unique features that could, as a whole, make the tourist experience highly diversified and enriching.

Generally, the Azores' strategic planning as a tourist destination has been carried out with particular care regarding sustainability, despite some flaws. Due to the need to protect the region's competitive advantages-i.e., its natural assets and high levels of sustainability-a suitable model must be followed, at the same time as new products are developed, in order to increase the value of the experiences in the region and to boost the destination's ability to evolve. Nature, Eco, and Adventure Tourism (NEAT) [37], imbued 
with sustainability principles, can be critical products in this paradigm. These are the ideals that underlie the PEMTA, which has chosen active nature-based tourism as the destination's priority.

\section{Methodology}

Taking into account the scope of this study, the authors needed to apply several research methodologies, namely: direct and indirect methods of analysis.

Consequently, the methodological approach consisted of the following four steps: survey design, data collection, case study analysis, and description of the results, ending with the discussion and conclusions.

\section{Survey Design and Implementation}

The survey was designed according to the need for online questionnaires. In this regard, we used a web survey using Google Forms. Although online surveys are susceptible to deviations in the results of an empirical study, such as in the respondents' age, the online survey methodology was chosen due to the restrictions imposed by the current Covid19 pandemic.

The survey was conducted by the Observatory of Tourism of the Azores (OTA), during December 2020, with Azorean tourist business managers to deepen the knowledge related to the theme of sustainability in tourist companies and the provision of Accessible and Inclusive Tourism services.

The target population (a group of individuals from which the sample might be drawn, also known as the theoretical population) consists of business managers of 2527 establishments of the touristic sector of Autonomous Regional of the Azores (AAR), 193 of which belong to the Accommodation sector and the remaining (93) are included in other tourism sectors.

The sample comprises 636 business managers of 623 establishments among those 2527 establishments, thus covering data referring to almost a quarter $(24.6 \%)$ of the AAR's touristic sector. According to the tourism sector in which they exercise their professional activity, the distribution of the 636 business managers who participated in the study is shown in Table 1.

Table 1. Distribution of business managers by type of tourism sector in the sample (valid \%).

\begin{tabular}{ccccc}
\hline & & $\mathbf{n}$ & $\mathbf{\%}$ & Valid $\mathbf{\%}$ \\
\hline \multirow{3}{*}{ Valid } & Accommodation & 478 & 75.2 & 75.6 \\
\cline { 2 - 5 } & Restaurants or similar & 54 & 8.5 & 8.5 \\
\cline { 2 - 5 } & Tourist Entertainment & 57 & 9.0 & 9.0 \\
\cline { 2 - 5 } & Travel agency or similar & 16 & 2.5 & 2.5 \\
\cline { 2 - 5 } & Rent-a-car & 8 & 1.3 & 1.3 \\
\cline { 2 - 5 } & Other & 19 & 3.0 & 3.0 \\
\hline \multirow{2}{*}{ Missing } & Total & 632 & 99.4 & 100.0 \\
\hline & 99 & 636 & 100.0 & \\
\hline
\end{tabular}

The majority $(75.6 \%)$ of the companies to which belong the business managers who participated in the present study fall into the Accommodation sector, $9 \%$ are in the tourist entertainment sector, $8.5 \%$ in the Catering sector and the like, $2.5 \%$ in the "Travel agency or similar" $(2.5 \%), 1.3 \%$ in the "Rent-a-car" Sector and 3\% in other sectors.

The statistical analysis of the collected data was performed using the IBM SPSS Statistics software. In addition to some graphical representations and tables of absolute frequencies and percentages, different Ascendant Hierarchical Cluster Analysis (AHCA) 
algorithms were applied to find a typology of a set of items concerning the adoption of sustainable practices. The AHCA was based on the Ochiai coefficient combined with three well-known classical aggregation criteria, namely, Single Linkage (SL), Complete Linkage (CL), and Average Linkage [38]. The evaluation of the obtained partitions was carried out based on the Global Statistics of Levels, STAT (see: [39,40]).

\section{Results}

Table 2 presents some summary statistics referring to the number of employees of the participating companies, noting that the most predominant response was zero, which indicates that many of the companies are family businesses, with no permanent/fixed-term contracts or for a period exceeding 12 months or contracts for a period less than 12 months.

Table 2. Values regarding the number of employees—on 31 August 2019.

\begin{tabular}{lccccc}
\hline & $\mathbf{n}$ & Mean & Median & Mode & $\begin{array}{c}\text { Standard } \\
\text { Deviation }\end{array}$ \\
\hline $\begin{array}{l}\text { Number of employees as of 31 } \\
\begin{array}{l}\text { August 2019, with a permanent } \\
\text { contract or for more than } \\
12 \text { months }\end{array}\end{array}$ & 591 & 5.28 & 1.00 & 0.00 & 37.359 \\
\hline $\begin{array}{l}\text { Number of employees as of 31 } \\
\text { August 2019, seasonal/with a } \\
\text { term contract of fewer than } \\
12 \text { months }\end{array}$ & 576 & 1.82 & 0.00 & 0.00 & 10.816 \\
\hline $\begin{array}{l}\text { Number of women employed } \\
\text { as of 31 August 2019 }\end{array}$ & 589 & 3.75 & 0.00 & 0.00 & 28.307 \\
\hline
\end{tabular}

This fact is mainly due to the structure/composition of the Azores Autonomous Region business sector. According to Sardinha [41]: "The Azores Autonomous Region shows in 2017, 27174 companies, of which 26310 were micro-enterprises, 747 small companies, 103 medium-sized companies, and 14 large companies". Regarding the evolution of the business sector between 2008 and 2017, it should be noted that micro-enterprises represented, in that period, more than $96 \%$ of the total companies in the Region. Altogether, micro-enterprises, together with small companies, represented more than $99 \%$ of all companies. In contrast, medium and large companies represented less than $1 \%$ of the Azores companies' total number [39].

The distribution of the surveyed managers by islands, taking into account the island where the companies are located, is shown in Table 3.

Table 3. Distribution of the surveyed managers, taking into account the island on which the companies are located.

\begin{tabular}{cccccc}
\hline & Islands & $\mathbf{n}$ & $\mathbf{\%}$ & Valid \% \\
\hline \multirow{7}{*}{ Valid } & Santa Maria & 19 & 3.0 & 3.0 \\
\cline { 2 - 5 } & São Miguel & 335 & 52.7 & 53.2 \\
\cline { 2 - 5 } & Terceira & 87 & 13.7 & 13.8 \\
\cline { 2 - 5 } & Graciosa & 12 & 1.9 & 1.9 \\
\cline { 2 - 5 } & São Jorge & 28 & 4.4 & 4.4 \\
\hline Pico & 62 & 9.7 & 9.8 \\
\hline & Faial & 51 & 8.0 & 8.1 \\
\hline & Flores & 34 & 5.3 & 0.3 \\
\hline
\end{tabular}


Table 3. Cont.

\begin{tabular}{lcccc}
\hline & Islands & $\mathbf{n}$ & $\mathbf{\%}$ & Valid \% \\
\hline Missing & Total & 630 & 99.1 & 100.0 \\
\hline Total & 99 & 6 & 0.9 & \\
\hline
\end{tabular}

Considering the responses of the 625 managers who reported having at least one month of operation, it was found that the period in which more companies are operating are the months between May and October, as shown in Table 4.

Table 4. The annual operating period of companies: percentage in relation to the total of responses and in relation to the number of valid cases (625).

\begin{tabular}{llccc}
\hline Months & $\mathbf{n}$ & \% of Answers & \% of Cases * \\
\hline & January & 512 & $7.7 \%$ & $81.9 \%$ \\
\hline February & 518 & $7.8 \%$ & $82.9 \%$ \\
\hline March & 533 & $8.0 \%$ & $85.3 \%$ \\
\hline April & 545 & $8.2 \%$ & $87.2 \%$ \\
\hline May & 569 & $8.6 \%$ & $91.0 \%$ \\
\hline June & 582 & $8.8 \%$ & $93.1 \%$ \\
\hline July & 593 & $9.0 \%$ & $94.9 \%$ \\
\hline August & 594 & $9.0 \%$ & $95.0 \%$ \\
\hline & September & 594 & $9.0 \%$ & $95.0 \%$ \\
\hline & October & 572 & $8.6 \%$ & $91.5 \%$ \\
\hline
\end{tabular}

*\% in relation to the total of valid cases (625 out of 636$)$.

Figure 1 contains a summary of the evolution of the leading tourism performance indicators in the Azores over the past few years in employees' perception.

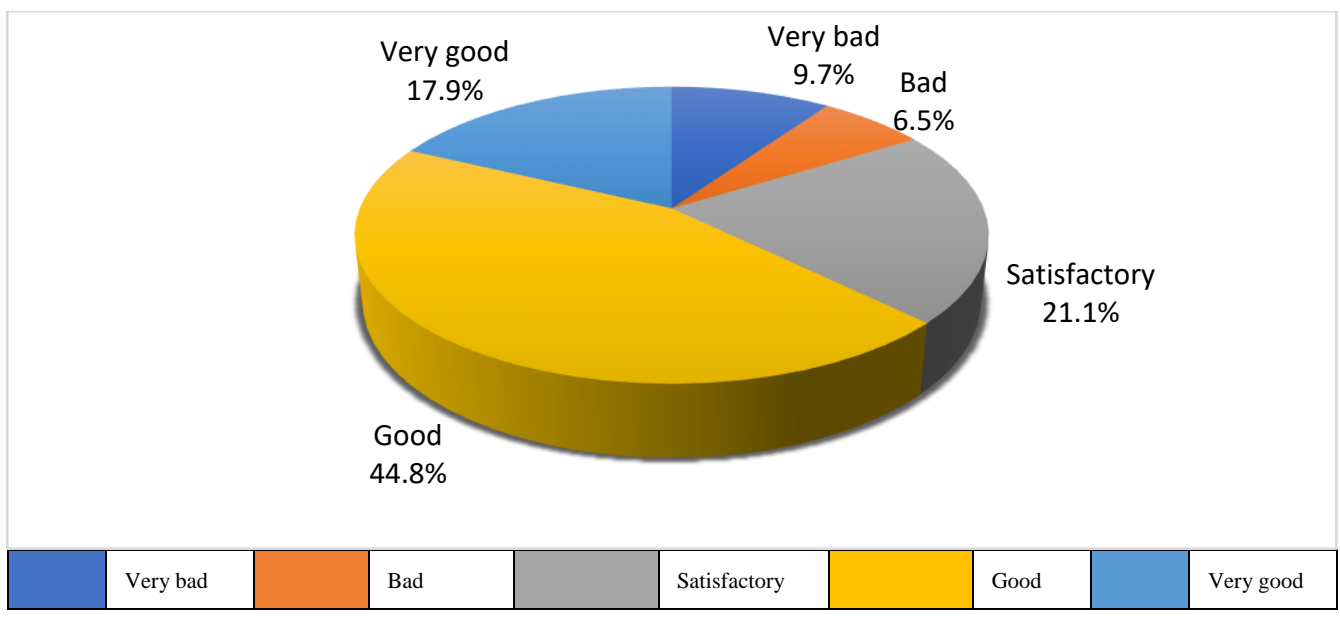

Figure 1. Evolution of the leading tourism indicators in the Azores over the past few years, in the perception of employees. 
Regarding the evaluation of the evolution of the leading tourism indicators in the Azores over the past few years, according to the perception of employees, it should be noted that the majority $(61.8 \%)$ of employees rated this evolution as "Good" $(44.8 \%)$ or "Very Good" (17.9\%), and 21.1\% rated this evolution as "Satisfactory." Only 9.7\% rated this evolution as "Very bad" and 6.5\% as "Bad."

From the percentage values presented in Table 5, it is possible to conclude that the sustainable practices most frequently adopted by the companies that participated in the study are the following: prioritize the purchase of regional goods and services (94.7\%); selective waste separation (94.5\%); minimize the use of hazardous substances or replace them with less hazardous products $(92.3 \%)$; ensure the proper final destination of wastewater (public sanitation, septic tank) (88.8\%); and adopt purchasing criteria that take into account environmentally friendly products or services (88.6\%).

Table 5. Adoption of sustainable practices (21 items).

\begin{tabular}{|c|c|c|c|}
\hline & Description of the 21 Items & No $(\%)$ & Yes $(\%)$ \\
\hline 1 & Are you aware of the Sustainable Tourism initiatives in the Azores? & 21.1 & 78.9 \\
\hline 2 & Have you defined your company's mission, vision, and values? & 19.3 & 80.7 \\
\hline 3 & Do you set goals and objectives on a regular basis? & 34.5 & 65.5 \\
\hline 4 & $\begin{array}{l}\text { If so, do the goals and objectives incorporate at least one aspect } \\
\text { of sustainability? }\end{array}$ & 14.1 & 85.9 \\
\hline 5 & Do you have a customer opinion evaluation system in place? & 26.4 & 73.6 \\
\hline 6 & $\begin{array}{l}\text { Have you assessed the impact of your activity on the environment } \\
\text { and local development? }\end{array}$ & 70.7 & 29.3 \\
\hline 7 & Has it prioritized the purchase of regional goods and services? & 5.3 & 94.7 \\
\hline 8 & $\begin{array}{l}\text { Have you adopted purchasing criteria that take into account } \\
\text { environmentally friendly products or services? }\end{array}$ & 11.4 & 88.6 \\
\hline 9 & $\begin{array}{l}\text { Do you regularly organize voluntary actions with a positive impact } \\
\text { on the local community? }\end{array}$ & 74.9 & 25.1 \\
\hline 10 & Does it selectively separate waste? & 5.5 & 94.5 \\
\hline 11 & Do you implement measures to reduce waste? & 27.1 & 72.9 \\
\hline 12 & $\begin{array}{l}\text { Does it make customers aware of water and energy savings } \\
\text { (through leaflets or others)? }\end{array}$ & 43.4 & 56.6 \\
\hline 13 & Do you implement measures to reduce energy consumption? & 29.4 & 70.6 \\
\hline 14 & $\begin{array}{l}\text { Do you use alternative / renewable energies (solar, photovoltaic, } \\
\text { or other)? }\end{array}$ & 70.1 & 29.9 \\
\hline 15 & $\begin{array}{l}\text { Does it ensure the proper final destination of wastewater (public } \\
\text { sanitation, septic tank)? }\end{array}$ & 11.2 & 88.8 \\
\hline 16 & $\begin{array}{l}\text { Do you purchase biodegradable detergents, biological fertilizers, } \\
\text { and "environmentally friendly" products? }\end{array}$ & 29.8 & 70.2 \\
\hline 17 & $\begin{array}{l}\text { Does it minimize the use of dangerous substances or replace them } \\
\text { with less hazardous products? }\end{array}$ & 7.7 & 92.3 \\
\hline 18 & Are employees trained to deal with hazardous substances? & 34.8 & 65.2 \\
\hline 19 & $\begin{array}{l}\text { Does it train and motivate employees to implement } \\
\text { sustainable practices? }\end{array}$ & 21.9 & 78.1 \\
\hline 20 & $\begin{array}{l}\text { Does your company contribute to the protection and conservation } \\
\text { of biodiversity? }\end{array}$ & 23.4 & 76.6 \\
\hline 21 & $\begin{array}{l}\text { Does the company have any environmental certification or } \\
\text { accreditation (ISO or other)? }\end{array}$ & 83.5 & 16.5 \\
\hline
\end{tabular}


In the perception of managers who answered the questionnaire, the vast majority of companies that participated in the study do not have any ISO environmental certification, or any other type of accreditation (83.5\%). They also do not organize voluntary actions with a positive impact on the local community $(74.9 \%)$. They never assessed the impact of its activity on the environment and regional development (70.7\%). They do not use alternative/renewable energies, such as solar, photovoltaic, or other $(70.1 \%)$. Therefore, it will be useful to promote awareness actions on the use of such practices among managers of Azorean tourist companies.

Of the 406 entrepreneurs surveyed who highlighted at least one of the four sustainability axes listed (Environmental, Social, Cultural, Economic), it was found that $67 \%$ (corresponding to $34 \%$ of the answers given) consider that their companies have their goals and objectives defined in the Environmental axes, $66.7 \%$ in the Economic axis (corresponds to $33.9 \%$ of the answers given), $36.9 \%$ in the Social axis and $26.4 \%$ in the Cultural axis, as shown in the results presented in Table 6 . Thus, the results suggest that most managers in the Region have concerns related to the environmental sustainability axis. However, there is still room to extend this awareness to more managers.

Table 6. Axes of environmental sustainability: percentage in relation to total responses and with regard to the number of valid cases (406).

\begin{tabular}{ccccc}
\hline Sustainability Axis & $\mathbf{n}$ & \% of Answers & \% of Cases * \\
\hline Environmental & 272 & $34.0 \%$ & $67.0 \%$ \\
\hline Social & 150 & $18.8 \%$ & $36.9 \%$ \\
\hline Cultural & 107 & $13.4 \%$ & $26.4 \%$ \\
\hline Total & Economic & 271 & $33.9 \%$ & $66.7 \%$ \\
\hline
\end{tabular}

*\% in relation to the total of valid cases (406 out of 636 respondents).

Of the 292 (out of 636) participating managers who selected at least one of the listed aspects designed to make companies accessible, the majority (61.3\%) selected the answer option "Creation of adequate parking"; $32.5 \%$ indicated "Adoption in rooms and sanitary facilities"; $31.2 \%$ a Placement of ramps; $25.3 \%$ a Training of human resources (employees); $22.6 \%$ indicated the "Use of alternative means of communication"; and 20.2\% referred to "Adoption of measures taken indoors and in the hallways" (Table 7).

Table 7. Aspects that made the company's facilities accessible: percentage of the total number of responses and percentage of the total number of valid cases (292).

\begin{tabular}{llccc}
\hline Aspects that Made the Company's Facilities Accessible & n & \% of Answers & \% of Cases * \\
\hline Creation of adequate parking & 179 & $27.9 \%$ & $61.3 \%$ \\
\hline Placement of ramps & 91 & $14.2 \%$ & $31.2 \%$ \\
\hline Placement of elevators & 34 & $5.3 \%$ & $11.6 \%$ \\
\hline Adoption of measures taken indoors and in the hallways & 59 & $9.2 \%$ & $20.2 \%$ \\
\hline Adoption in rooms and sanitary facilities & 95 & $14.8 \%$ & $32.5 \%$ \\
\hline Braille information & 5 & $0.8 \%$ & $1.7 \%$ \\
\hline Use of alternative means of communication & 66 & $10.3 \%$ & $22.6 \%$ \\
\hline Training of human resources (employees) & 74 & $11.5 \%$ & $25.3 \%$ \\
\hline Adapted animation activities & 26 & $4.1 \%$ & $8.9 \%$ \\
\hline Other & 12 & $1.9 \%$ & $4.1 \%$ \\
\hline
\end{tabular}

$* \%$ in relation to the total of valid cases (292 out of 636 respondents). 
Regarding the "Other" category, the respondents specified some interesting aspects, such as air conditioning, fire doors, heated swimming pools, recycling, and all bedrooms offered on a single floor.

The AHCA of the 21 items of Table 5 provided some relevant clustering results in the field of Adoption of sustainable practices. According to the Global Statistics of Levels (STAT) values, the best partition is the following partition into eight clusters (STAT $=12.738$ ), obtained at level 16 by all aggregation criteria.

So, Cluster 1: $\{1,2,3,4,7,10,8,17,15,11,19,20,13,16\}$; Cluster 2: $\{5\}$; Cluster 3: $\{18\}$; Cluster 4: $\{12\}$; Cluster 5: $\{14\}$; Cluster 6: $\{6\}$; Cluster 7: $\{9\}$; Cluster 8: $\{21\}$.

In this regard, Figure 2 shows the dendrogram provided by the Complete Linkage method, where it is possible to verify that Cluster 1 can be subdivided into seven interesting subclusters, namely:

- Subcluster 1: $\{3,4,2\}$, which contains items related to set goals and objectives on a regular basis; the inclusion/incorporation of at least one aspect of sustainability in the context of the goals and objectives; and the definition of the company's mission, vision, and values;

- Subcluster 2: $\{7,10,8,17\}$, that includes items referring to the prioritization of purchase of regional goods and services; selective waste separation; adoption of purchasing criteria that take into account environmentally friendly products or services; and minimization of the use of dangerous substances or their replacement by less hazardous products;

- Subcluster 3: $\{15\}$;

- Subcluster 4: $\{19,20,11\}$, that contains items referring to initiatives related to training and motivation of employees in order to implement sustainable practices; protection and conservation of biodiversity; and waste reduction.

- Subcluster 5: $\{13\}$;

- Subcluster 6: $\{16\}$;

- Subcluster 7: $\{1\}$.

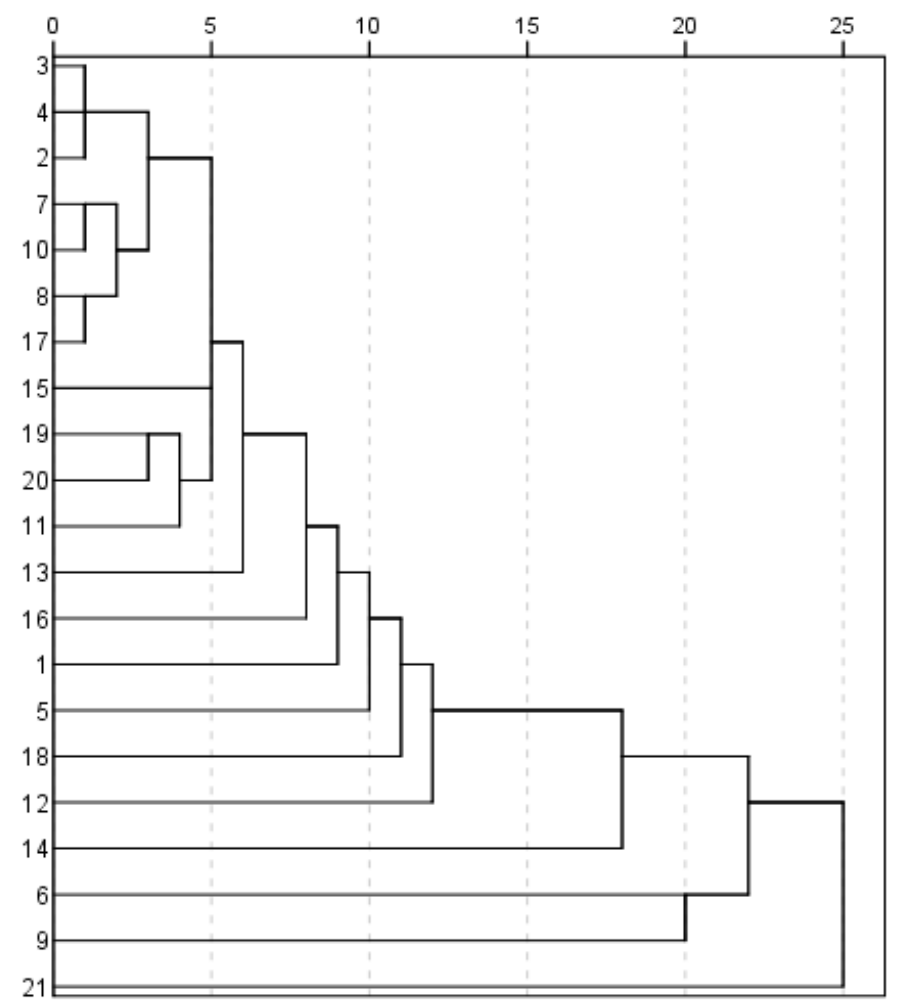

Figure 2. Dendrogram provided by the Ochiai coefficient combined with Complete Linkage. 


\section{Discussion and Conclusions}

This article aims at contributing to the theme of perceived sustainability measures taken by tourist companies and the provision of Accessible and Inclusive Tourism services in the Azores.

The study analyzes the perceptions of managers of tourism companies operating in the Azores on sustainability measures taken by Azorean tourism companies.

The sustainability of tourism in island territories is essential for its survival. Sustainable tourism covers the three aspects of sustainability, namely: the environmental, economic, and social aspects [42,43].

In 2020, the Azores' Regional Government concluded the firsts phase of a certification process for the Azores as a sustainable tourist destination, certified by EarthCheck, according to the principles of the Global Sustainable Tourism Council (GSTC). At the moment, the Azores are the only island destination in the world to hold this certification. In this context, the local DMO (destination manager office) launched the "Sustainability Chart," which was joined by several partner bodies in the Azores tourism sector, including the Azores Tourism Observatory (OTA). Subscribers to this chart undertake to adopt sustainability measures in their activities.

In this context of sustainability policies, OTA joined the UNWTO Sustainable Tourism Observatories network (INSTO), which has launched a survey of entrepreneurs and managers of Azorean tourist companies questioning the sustainability indicators adopted by companies.

Therefore, this article, using the data resulting from the survey launched, analyzes Azorean tourism managers' and entrepreneurs' perceptions regarding sustainability practices adopted by the surveyed tourist companies.

The research conducted reveals that $67 \%$ of the 406 entrepreneurs/managers surveyed believe that their companies pursue environmental sustainability goals (66.7\%). However, a lower percentage (36.9\%) perceive the existence of social sustainability goals, $33.9 \%$ of respondents perceive the adoption of objectives in terms of economic sustainability, and only $26.4 \%$ of respondents perceive measures and objectives in terms of cultural sustainability.

Thus, the conclusions of the study make it possible to formulate policy recommendations addressed to both tourist companies and regional authorities with responsibility for Azorean tourism, among which the following stand out: supporting Azorean tourist companies in adopting sustainability measures, reinforcing those of an economic nature and, above all, those of a cultural nature; and support the improvement of aspects that aim to make the company's infrastructures accessible and that make the Azores a more inclusive tourism destination.

This reveals the opportunity and the importance of this article when the sector is going through a pandemic crisis and when sustainability is a fundamental pillar of the competitiveness and survival of the Azores destination. In fact, the most recent studies on world tourism trends reveal a high potential demand as soon as the travel restrictions that will materialize end, above all, as soon as the populations are vaccinated and acquire group immunity.

Trends also reveal a preference for sustainable destinations like the Azores. Thus, it will be essential to reinforce sustainability perceptions, preparing the destination for post-Covid-19 recovery [21,44].

Finally, many studies reveal gaps between entrepreneurs' sustainability perceptions and those of tourists and the authorities responsible for tourist policies. Thus, a clue for future research in this area will be to analyze the perceptions of tourists, residents, and destination managers, the various partners of Azorean tourism in terms of the sustainability of the destination and its companies. Therefore, it is crucial to investigate the changes in entrepreneurs' perceptions regarding sustainability to meet the changes in tourists perceptions, eliminating the existing gaps. 


\subsection{Extracted Guidelines for the Promotion of Rural Tourism and Regional Sustainable} Development in the Azores Region

Moreover, if we look at this problem from a holistic perspective, through this research, the subsequent guidelines should be considered in the contribution of long-term territorial sustainability regarding sustainable tourism in the Azores Islands:

- $\quad$ stimulate entrepreneurship, linked with small and medium-sized businesses, promoting the variety of offers;

- prioritize rural tourism over mass tourism;

- foster closer cooperation among the public sector, the private sector, communities, and civil society;

- promote policies that focus on sustainable development aiming to create significant investments in infrastructure and services, focusing on accessibility by air;

- encourage the protection and conservation of ecological systems.

Furthermore, tourism is an innovative industrial sector. Developing a culture of tourism and services-service is not servitude; emphasizing vocational training with international inputs could help build a structured and profitable tourism industry based on diversification, destinations, and distinction.

In this regard, the tourism strategy should reinforce the value chain between the tourism attractions, stakeholders, and final markets to guarantee the destination's competitiveness and sustainability. When local growth stops in the Azores because of COVID-19 and when unemployment starts to increase, it is important to find new sources of growth in the short and medium terms. Tourism provides appropriate responses to economic needs and, as such, must be retained as a Strategic Development Policy by all local actors. That means focusing on the development of local resources, especially on rural tourism, and capturing external resources for a self-sustainable economic return, including direct and indirect jobs creation, with a variety of skill levels required to respond to the situation of Covid-19. The Azoreans themselves must be convinced that tourism is a credible development sector in the archipelago. Tourism development is also a vector of pride by putting forward the local and rural cultures outside of the archipelago and a vector of internationalization by boosting air supply and increased trade. Tourism development is a vital need to get the growth the Azores need to reduce the impact of the actual crisis and give rural society the development tools to include the archipelago in the world system. Therefore, the responsibility of all stakeholders is engaged towards the present and future generations, as with all complex and multi-player projects, the key is to take action.

The focus of the rural and peripheral areas will be targeted to improve local tourism development conditions and the consequent increase in value creation. This will allow farmers, fishers, and many other stakeholders to have new income sources that improve their quality of life and reduce poverty and potential poverty. This new scenario can also contribute to less pronounced desertification of rural areas. It will give young people new opportunities to invest and develop their businesses and/or careers. On the other hand, the identification of rural features and characteristics can enhance new tourism products. This approach focused on the innovation of the tourism supply and the diversification of tourism activities by leveraging differentiating and unique local features.

The new model can also contribute to the societal challenge related to "Climate Action, Environment, Resources Efficiency, and Raw Materials," especially considering cultural heritage issues. This is an essential asset for general tourism development and is even more important in rural areas. Authenticity, history, stories, and traditions are vital for tourism and to peripheral areas' identity. The new model must be especially alert to these features and contribute to their protection, preservation, innovation, and ability to generate value for the local communities.

Therefore, there can clearly be relevant contributions to public policies and their evolution. These will result in a more coherent approach to tourism and rural development and affect end-users. On the one hand, it will benefit tourists, because they will have a broader and richer supply of activities, and, on the other hand, it will benefit local 
communities, since they will have additional revenues, more consumers for their goods, and new ways to value and protect their local traditions, identities, and heritage.

In concerned rural communities, the development of tourism associated with traditional activities and local communities will diversify income sources for many families. In turn, this situation will improve the local population's quality of life and create new investment and business opportunities, new jobs, poverty reduction, migration reduction, and an increase in the number of young people working for local companies and communities. This is the natural dynamic of an increasingly competitive Region or Country.

\subsection{Research Limitations and Prospective Research Lines}

Although this study enlarges our understanding of how the Azorean tourism companies on the sustainability perceive sustainable tourism in this Ultra-Peripheral territory as well as which should be the guidelines for the new tourism model followed by the Azores to promote rural tourism and regional sustainable development; however, many perspectives for future research persist. In fact, this study only covers a specific time-frame (December 2020). Accordingly, considering that this issue's rapid dynamics are even more visible in the actual pandemic crisis scenario, similar studies should be proceeded in the forthcoming months to monitor those perceptions about sustainable tourism development in the Azores region and define or re-design new guidelines or models.

Author Contributions: Conceptualization G.C., C.S. and R.A.C.; methodology, Á.S.; software, P.P.; validation, G.C., C.S. and S.F.; formal analysis, R.A.C. and Á.S.; investigation, S.F., R.A.C. and M.d.G.B.; resources, G.C. and C.S.; data curation, Á.S.; writing—original draft preparation, R.A.C.; writing-review and editing, R.A.C., G.C., Á.S. and P.P.; visualization, P.P.; supervision, C.S.; project administration, G.C. and R.A.C.; funding acquisition, G.C. All authors have read and agreed to the published version of the manuscript.

Funding: This paper is financed by Portuguese national funds through FCT-Fundação para a Ciência e a Tecnologia, I.P., project number UIDB/00685/2020 and also by the project GREAT-Genuine Rural Experiences in the Azores Tourism, with the code: ACORES-01-0145-FEDER-000089. We are gratefully acknowledged financial support from FCT- Fundação para a Ciencia e Tecnologia (Portugal), national funding through research grant UIDB/04521/2020.

Institutional Review Board Statement: Not applicable.

Informed Consent Statement: Not applicable.

Data Availability Statement: MDPI Research Data Policies.

Conflicts of Interest: The authors declare no conflict of interest.

\section{References}

1. Santos, R. O regresso dos Emigrantes Portugueses e o Desenvolvimento do Turismo em Portugal. Ph.D. Thesis, University of Aveiro, Aveiro, Portugal, 2013.

2. Morais, J.; Castanho, R.; Pinto-Gomes, C.; Santos, P. Merging Traditional Livelihood Activities with New Employment Opportunities Brought by Ecotourism to Iona National Park, Angola: Rethinking Social Sustainability. In Planeamiento Sectorial: Recursos Hídricos, Espacio Rural y Fronteras; Thomson, R., Ed.; Aranzadi: San Sebastián, Spain, 2018; pp. 293-303. ISBN 978-84-1309-065-8.

3. Morais, J.; Castanho, R.A.; Loures, L.; Pinto-Gomes, C.; Santos, P. Villagers' Perceptions of Tourism Activities in Iona National Park: Locality as a Key Factor in Planning for Sustainability. Sustainability 2019, 11, 4448. [CrossRef]

4. Van der Schyff, T. The Development and Testing of a Measurement Instrument for Regional Tourism Competitiveness Facilitating Economic Development. Ph.D. Thesis, North-West University (NWU), Potchefstroom, South Africa, 2021.

5. UNWTO (United Nations World Tourism Organization). International Recommendations for Tourism Statistics; United Nations World Tourism Organization: Madrid, Spain, 2008.

6. Santos, R.; Castanho, R.A.; Lousada, S. The Portuguese Emigrants' Return and the Impacts over Tourism Development in Rural Areas: Directions for a Sustainable Planning. In Espacios y Sociedades en Transformación; Thomson, R., Ed.; Aranzadi: San Sebastián, Spain, 2020; ISBN 978-84-1346-693-4.

7. Santos, R.; Castanho, R.A.; Lousada, S. Return Migration and Tourism Sustainability in Portugal: Extracting Opportunities for Sustainable Common Planning in Southern Europe. Sustainability 2019, 11, 6468. [CrossRef] 
8. Couto, G.; Castanho, R.A.; Pimentel, P.; Carvalho, C.B.; Sousa, Á. The Potential of Adventure Tourism in the Azores: Focusing on the Regional Strategic Planning. In Advances in Tourism, Technology and Systems. ICOTTS 2020. Smart Innovation, Systems and Technologies; Abreu, A., Liberato, D., González, E.A., Garcia Ojeda, J.C., Eds.; Springer: Singapore, 2021; Volume 209. [CrossRef]

9. Couto, G.; Castanho, R.A.; Sousa, A.; Pimentel, P.; Santos, C.; Carvalho, C. The Impacts of COVID-19 Crisis over the Tourism Expectations of the Azores Archipelago Residents. Sustainability 2020, 12, 7612. [CrossRef]

10. Ulucak, R.; Yücel, A.G.; İlkay, S.Ç. Dynamics of tourism demand in Turkey: Panel data analysis using gravity model. Tour. Econ. 2020, 26, 1394-1414. [CrossRef]

11. Labrianidis, L.; Ferrão, J.; Hertzina, K.; Kalantaridis, C.; Piasecki, B.; Sma-llbone, D. The Future fd Europe's Rural Periphery; Final Report. 5th Framework Programme of the European Community; 2003. Available online: https://cordis.europa.eu/docs/ projects / files/HPSE/HPSE-CT-1999-00013/100124141-6_en.pdf (accessed on 30 March 2021).

12. Market Potential and New Firm Formation. Available online: https://www.researchgate.net/publication/46470124_Market_ Potential_and_New_Firm_Formation (accessed on 30 March 2021).

13. Williams, A. (Ed.) Introduction. In Southern Europe Transformed-Political and Economic Change in Greece, Italy, Portugal and Spain; Harper \& Row: London, UK, 1984; pp. 1-32.

14. Fleischer, A.; Felsenstein, D. Support for Rural Tourism—Does It Make a Difference? Ann. Tour. Res. 2000, 27, 1007-1024. [CrossRef]

15. Mahony, K.; Zyl, J. The Impacts of Tourism Investment on Rural Communities: Three Case Studies in South Africa. Dev. South Afr. 2002, 19, 83-103. [CrossRef]

16. Mazumder, H.; Ahmed, M.; Al-Amin, Q. Estimating Total Contribution of Tourism to Malaysia Economy. Int. J. Bus. Manag. Soc. Sci. 2009, 2, 146-159.

17. Castanho, R.A.; Couto, G.; Pimentel, P.; Carvalho, C.; Sousa, Á.; Garrido Velarde, J. Assessing the impacts of public policies over tourism in Azores Islands. A research based on tourists and residents perceptions. Wseas Trans. Environ. Dev. 2020. [CrossRef]

18. Koçak, E.; Ulucak, R.; Şentürk Ulucak, Z. The impact of tourism developments on CO2 emissions: An advanced panel data estimation. Tour. Manag. Perspect. 2020, 33, 100611. [CrossRef]

19. Castanho, R.A.; Couto, G.; Santos, R. Introductory Chapter: Rural Tourism as a Catalyst for Sustainable Regional Development of Peripheral Territories. 2021. Available online: https://www.researchgate.net/publication/349670226_Introductory_Chapter_ Rural_Tourism_as_a_Catalyst_for_Sustainable_Regional_Development_of_Peripheral_Territories (accessed on 30 March 2021).

20. Roy, S.C.; Roy, M. Tourism in Bangladesh: Present status and future prospects. Int. J. Manag. Sci. Bus. Adm. 2015, 1, 53-61.

21. Castanho, R.A.; Gualter, C.; Pimentel, P.; Carvalho, C.; Sousa, Á.; Graça Batista, M. How an infectious disease could influence the development of a region: The evidence of the SARS-COV-2 outbreak over the Tourism Intentions in Azores Archipelago. Duzce Med. J. 2021, 23 (Supp. S1), 106-112. [CrossRef]

22. Karalkova, Y. Rural Tourism Destination Competitiveness: Portugal vs. Belarus. Master's Thesis, Polytechnic Institute of Bragança, Bragança, Portugal, 2016.

23. Phillip, S.; Hunter, C.; Blackstock, K. A typology for defining agritourism. Tour. Manag. 2010, 31, 754-758. [CrossRef]

24. Sonnino, R. For a 'Piece of Bread'? Interpreting sustainable development through agritourism in Southern Tuscany. Sociol. Rural. 2004, 44, 285-300. [CrossRef]

25. Barbieri, C.; Mshenga, P.M. The role of the firm and owner characteristics on the performance of agritourism farms. Sociol. Rural 2008, 48, 166-183. [CrossRef]

26. Gordon, J.E. Geoheritage, geotourism and the cultural landscape: Enhancing the visitor experience and promoting geoconservation. Geosciences 2018, 8, 136. [CrossRef]

27. Mitchell, J.; Li, S. Autonomy found: Estimating the local benefit from tourism in SIDS-the case of Cape Verde. J. Policy Res. Tour. Leis. Events 2017, 9, 182-200. [CrossRef]

28. Panfiluk, E. Impact of a tourist event of a regional range on the development of tourism. Soc. Behav. Sci. 2015, 213, 1020-1027. [CrossRef]

29. Smith, S.L. Tourism Analysis: A Handbook, 2nd ed.; Routledge: New York, NY, USA, 2014.

30. Andrades, L.; Dimanche, F. Destination competitiveness and tourism development in Russia: Issues and challenges. Tour. Manag. 2017, 62, 360-376. [CrossRef]

31. Rizzi, P.; Graziano, P. Regional perspective on global trends in tourism. Emerg. Issues Manag. 2017, 3, 11-26. [CrossRef]

32. Folgado-Fernández, J.A.; Di-Clemente, E.; Hernández-Mogollón, J.M. Food Festivals and the Development of Sustainable Destinations. The Case of the Cheese Fair in Trujillo (Spain). Sustainability 2019, 11, 2922. [CrossRef]

33. Elmo, G.C.; Arcese, G.; Valeri, M.; Poponi, S.; Pacchera, F. Sustainability in Tourism as an Innovation Driver: An Analysis of Family Business Reality. Sustainability 2020, 12, 6149. [CrossRef]

34. Castanho, R.A.; Couto, G.; Pimentel, P.M. Principles of Sustainable Tourism and Cultural Management in Rural and Ultraperipheral Territories: Extracting Guidelines for its application in the Azores Archipelago. Cult. Manag. Sci. Educ. 2020, 4, 9-24. [CrossRef]

35. Couto, G.; Pimentel, P.; Ponte, J.C.; Gonçalves, P.; Duarte, D.; Arruda, A.; Rodrigues, F. Azores: INVESTOR'S Guide to Sustainable Tourism; FLAD—Fundação Luso Americana para o Desenvolvimento: Ponta Delgada, Spain, 2018.

36. Silva, F.; Almeida, M. Sustentabilidade do Turismo na Natureza nos Açores-O Caso do Canyoning. In Turismo e Desporto na Natureza; Almeida, E.M., Ed.; Asso-ciação de Desportos de Aventura Desnível: Estoril, Portugal, 2013; pp. 5-19. 
37. Buckley, R. Neat trends: Current issues in nature, eco and adventure tourism. Int. J. Tour. Res. 2000, 2, 437-444. [CrossRef]

38. Anderberg, M.R. Cluster Analysis for Applications; Elsevier BV Academic Press: New York, NY, USA, 1973.

39. Bacelar-Nicolau, H. Contributions to the Study of Comparison Coefficients in Cluster Analysis. Ph.D Thesis, Universidade de Lisboa, Lisboa, Portugal, 1980.

40. Lerman, I.-C. Foundations and Methods in Combinatorial and Statistical Data Analysis and Clustering. In Secure Information Management Using Linguistic Threshold Approach; Springer Science and Business Media LLC: Berlin/Heidelberg, Germany, 2016.

41. Sardinha, L.F.; Sousa, Á.; Leite, E.; Fernandes, P.F. O setor empresarial nas regiões ultraperiféricas portuguesas-Uma década em perspetiva/ The business sector in the Portuguese outermost regions-A decade in perspective. Econ. Bus. Entrep. Mag. Cplp 2020, 6, 1-24.

42. Santos, L.; Cardoso, L.; Araújo-Vila, N.; Fraiz-Brea, J. Sustainability Perceptions in Tourism and Hospitality: A Mixed-Method Bibliometric Approach. Sustainability 2020, 12, 8852. [CrossRef]

43. Melo, F.V.S.; Farias, S.A. Sustainability communication and its effect in consumer intention to visit a tourist destination. Tour. Manag. Study 2018, 14, 36-44. [CrossRef]

44. Baum, T.; Hai, N.T.T. Hospitality, tourism, human rights and the impact of COVID-19. Int. J. Contemp. Hosp. Manag. 2020, 32, 2397-2407. [CrossRef] 